\title{
Consideration of land use in the evaluation of erosive processes in gully erosion
}

\author{
Consideração do uso e ocupação na avaliação dos processos erosivos \\ de uma voçoroca
}

\author{
Tamara Vieira Pascoto' \\ Simone Andrea Furegatti" \\ Anna Silvia Palcheco Peixoto'"I
}

\begin{abstract}
There are several factors that directly or indirectly influence erosion processes. In order to properly understand the behavior of these processes, some factors need to be analyzed together. Determining them wrongly can compromise the study resulting in wrong actions. For this reason, methodologies are always sought to measure them quantitatively and qualitatively in the most accurate possible way. Land use is one of the main factors liable to inaccuracies in its determination. To use this parameter in mapping erosive processes, researchers need to delimit it, classify it, and measure it. In order to better understand the complexity of considering this parameter, the present study analyzed an erosive feature that, although stabilized, has a component in constant development. Initially, a visual analysis indicated the same classification of land use for both conditions, despite having different behaviors, leading to the need for a detailed analysis. Such analysis comprised a historical survey through aerial photos and interviews with residents and employees of the city hall about the evolution of the feature from 2008 to 2019. It also included the analysis of other influencing factors that could be responsible for this difference in behavior in the area. Two different traces of the contribution areas of the gully and branch were also considered. One considering only aerial images, and the other considering the knowledge acquired during the research about the evolution of the feature. It was concluded, then, that an analysis of the use-only occupation factor based on aerial images can accentuate the inaccuracy of the measurement of this factor.
\end{abstract}

Keywords: Urban Erosion; Land Use; Erosion Factors.

\section{Resumo}

Diversos são os fatores que influenciam direta ou indiretamente nos processos erosivos. A fim de entender de maneira adequada o comportamento dos processos, tais fatores necessitam de uma análise em conjunto. Determiná-los de maneira errônea pode comprometer o estudo, levando à ações equivocadas. Por isso buscase sempre metodologias para mensurá-los quantitativamente e qualitativamente da maneira mais precisa possível. O uso e ocupação é um dos principais fatores passíveis de imprecisões na sua determinação. Para utilizar esse parâmetro em mapeamento de processos erosivos, os pesquisadores precisam delimitá-lo,

\footnotetext{
' Universidade Estadual Paulista "Júlio de Mesquita Filho", Bauru, SP, Brasil - tamara.pascoto@unesp.br.

" Universidade Estadual Paulista "Júlio de Mesquita Filho", Bauru, SP, Brasil - simone.furegatti@unesp.br.

II' Universidade Estadual Paulista "Júlio de Mesquita Filho", Bauru, SP, Brasil - anna.peixoto@unesp.br.
} 
classificá-lo e mensurá-lo. A fim de entender melhor a complexidade de consideração desse parâmetro, o presente estudo analisou uma feição erosiva que, apesar de estabilizada, possui um braço em constante desenvolvimento. Inicialmente, uma análise visual indicou a mesma classificação do uso e ocupação para ambas as condições, apesar de apresentarem comportamentos diferentes, levando a necessidade de uma análise detalhada. Tal análise compreendeu um levantamento histórico, através de fotos aéreas e de entrevistas com moradores e funcionários da Prefeitura Municipal, sobre a evolução da feição entre os anos de 2008 a 2019. Compreendeu, também, a análise de outros fatores influenciadores que poderiam ser responsáveis por essa diferença de comportamento na área. Foram considerados, ainda, dois diferentes traçados das áreas de contribuição da boçoroca e do braço, um considerando apenas imagens aéreas, e outro considerando os conhecimentos adquiridos durante a pesquisa, sobre a evolução da feição. Concluiu-se, então, que uma análise do fator uso e ocupação apenas visual baseadas em imagens aéreas pode acentuar a imprecisão da mensuração desse fator.

Palavras-chave: Erosão Urbana; Uso e Ocupação; Fatores Erosivos. 


\section{Introduction}

In studies on accelerated natural processes with varied themes such as erosion, silting, floods, and mass movements, the land use of soil is one of the main factors that directly indicate anthropic action. Several areas related to urban planning and environmental monitoring map this parameter, classify the area in different categories, and measure them in different ways. The land use mapping method is directly influenced by the scale of work which can be performed, for example, with the aid of aerial and satellite images (TRINDADE E RODRIGUES, 2016; NASCIMENTO E FERNANDES, 2017; PENA E LADISLAU , 2017; TAGLIARINI ET AL., 2017; COSTA ET AL., 2018; SANTOS ET AL., 2019).

Among the researched authors, the categories used for classification are related to the types of occupation that each studied place presents. Trindade and Rodrigues (2016), for example, adopted Agriculture, Pasture, Native Vegetation, and Urban Area because they are the most representative in the studied watershed in the cities of Catalão and Goiandria in Goiás State. Nascimento and Fernandes (2017) divided the studied watershed in Forest, Clean Pasture, Dirty Pasture, Pasture Regeneration, Secondary Vegetation, Mosaic of Occupations, Urban Area, Mining, and Unobserved Area. Pena and Ladislau (2017), since they were studying the land use parameter in a sub-basin located entirely in an urban area related to the management of the area, divided it into categories of Density Zone, Preferential Density Zone, Restricted Density Zone, Large Area Equipment, Special Social Interest Zone, Protection Zone, and Environmental Preservation Zone.

In studies on erosion processes and occurrence, the measurement of land use also occurs in different ways depending on the goal of the study. Costa et al. (2018) determined importance for the parameter, through consultation with specialists who took into account the occurrence of erosive processes in the categories determined in the study area in order to map the runoff and accelerated erosion in an urban area.

To study the influence of land use in relation to susceptibility to laminar erosion over the years, Trindade and Rodrigues (2016) determined the percentage of the area that each category had in the studied region in five years (from 2001 to 2015). Aragão et al. (2011) matrixed the erosion susceptibility map with the land use plot to chart the potential for 
laminar erosion in the Japaratuba River basin in Sergipe State, adopting the methodology developed by Salomão (1999).

The study of land land use, especially when close to urban areas, must always be linked to the study of anthropic action in the study area. In these regions, the main anthropic actions are correlated with engineering works that move large portions of soil, whether for opening trenches or carrying out subdivisions due to urban expansion or the construction of roads. These works change the main characteristics of the soil structure, influencing soil properties such as density and permeability and also the surface of the land such as ramp length, slope shape, and roughness.

All of these characteristics directly alter the surface runoff behavior of the region. For instance, the different combinations of slope shapes (concave, convex, and flat) generate different zones of convergence and divergence of water flow in the soil (DIAS E HERRMANN, 2002). According to Gray (2016), the slopes of concave shapes generate less sediment than the flat shapes. This may indicate that changing the shape of a natural slope to a flat slope, as occurs in asphalt engineering works, can further accelerate erosion processes.

Depending on the intensity of the erosive processes, erosive features of different dimensions and behavior can develop, which can start from a groove (when small channels are formed), passing through ravines, reaching gully erosions which have steep walls, unstable slopes, whether or not there is internal erosion and outcropping of the water table (FOSTER, 1986; IWASA and FENDRICH, 1998; KARMANN, 2000; CAMAPUM DE CARVALHO e. al., 2006). These erosive features, when located close to urban areas, cause serious economic and social problems to the city and, in addition to destroying existing infrastructures, put the population at risk due to possibility of leading to the collapse of buildings.

Knowing that land use is one of the main factors influencing erosive processes (PASCOTO, 2020), the mapping, classification, and correct measurement of this parameter becomes essential to improve the accuracy of the results obtained in the erosion studies of the ground. Due to its complexity, the determination of this parameter requires caution, in addition to an individual study of the occupation of the region. As an example, Costa et al. (2018) adopted the value of 30 for a wide range of land occupation, covering roads, 
urbanized area, and exposed soil, among others. In his work, grouping all these parameters did not lead to failures in the interpretation of the behavior of erosive processes.

However, Pascoto (2020) adopted this same classification in another area of study and noted that the classification used was not adequate. The author believes that this may have occurred because the classification "urbanized area" encompasses a wide range of occurrences: in the center of cities, where almost the entire surface is waterproofed, the probability of developing linear erosions is very low, regardless of having an efficient or sufficient drainage system, because even with a concentrated and high surface flow, waterproofing protects the ground. In the peripheral regions, there is already an interface situation, with a part waterproofed and another part still without occupation.

In these regions, the drainage system discharge is often done inappropriately in relation to the dynamics existing at this interface, concentrating the energy of the flow coming from a large area. Therefore, when this situation occurs in regions with soils susceptible to erosive processes, it can trigger linear erosive processes.

Thus, with the intention to expand the discussion on the subject, this research aimed to analyze the influence of the land use factor of the soil in a particular situation, in which a large proportion erosive feature, a branched gully which is stabilized for decades, has one branch which continues to develop despite the fact that the whole feature apparently has the same values for the factors influencing erosive processes.

\section{Material and Methods}

\subsection{Study area}

São Manuel is located in the west center of São Paulo State (Figure 1) and has a tropical climate of altitude, with dry and cold winters in the months of June, July, and August. Moreover, it is characterized by predominant rains in the summer and an average annual precipitation of $1465 \mathrm{~mm}$. The urban area of the city is located in the UGRHI (Hydrographic Units for Water Resources Management) 13: Tietê - Jacaré and the clay soils of the city are associated with the Serra Geral Formation and the sandy soils are present at the Adamantina 
Formation and Botucatu Formation (STATE SECRETARIAT OF SANITATION AND WATER RESOURCES, 2017).

Figure 1 - Study area location with emphasis on the aerial photo for the developing branch of the studied erosive feature

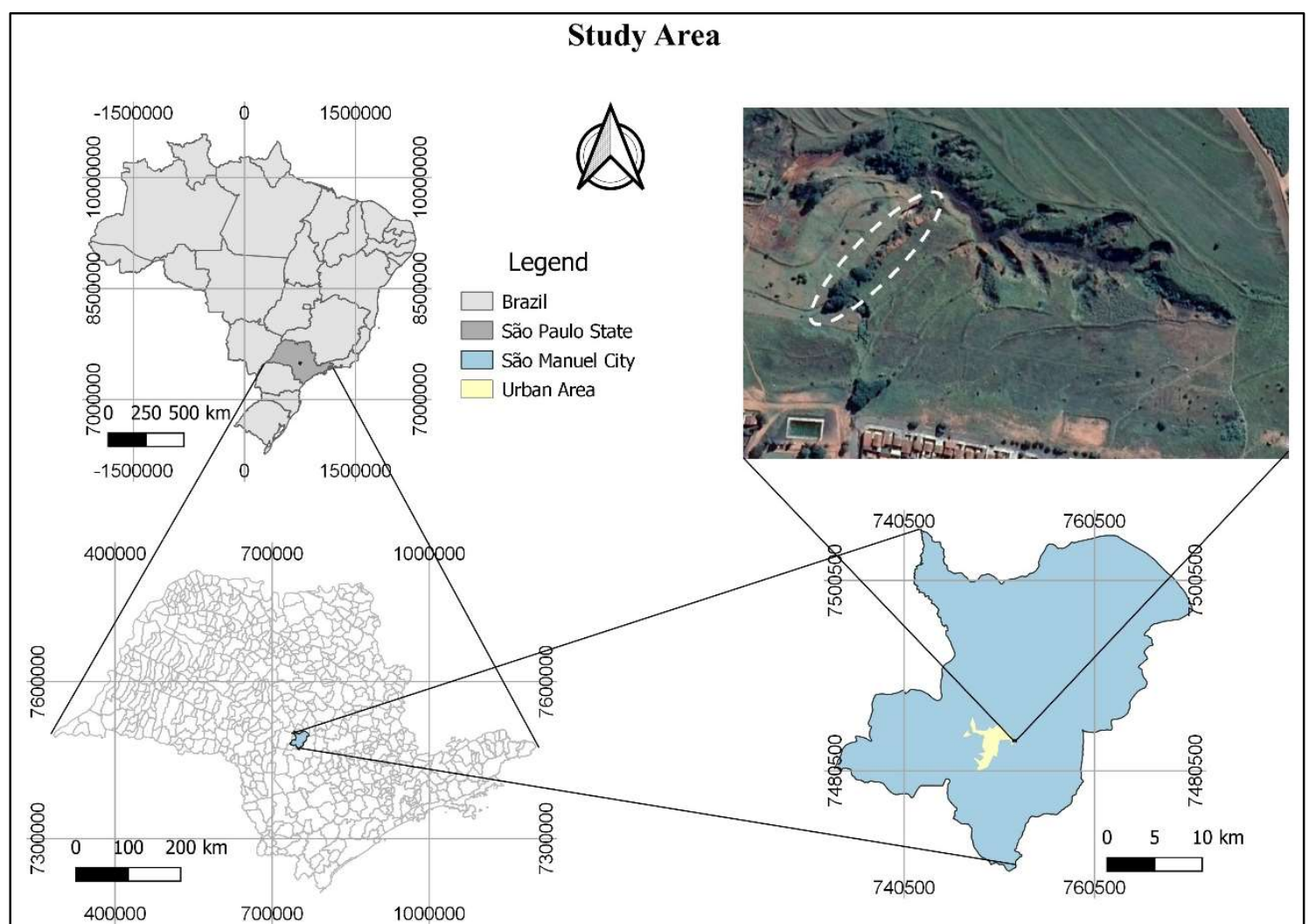

Pascoto et al. (2018) surveyed and classified nine erosive features in the urban area of São Manuel City. Subsequently, Pascoto (2020) modified this classification, in which two were recovered, two were classified as margin erosions, and the others (five features) were classified as linear water erosions, being a ravine and four gullies. Due to this study, it was observed that one of the gullies located in the Ribeirão Paraíso Sub-basin was stabilized, despite its great extension, presenting, however, one of the branches still under development. The study area, therefore, comprises the area of contribution of the erosive feature, classified as gully. Figure 1 shows the location of the study gully erosion in São Manuel City (highlighted, in white, for the developing branch). 


\subsection{Research procedures}

In order to make a more detailed analysis of the influence of the land use factor in erosive processes and understand the complexity of this analysis, the present study was based on the perception of similarities and differences that it contained in an area with stabilized gully erosion with only one branch showing rapid development.

Initially, a trace of the feature historical evolution was made. Aerial photos taken from Google Earth from 2008 to 2019 were analyzed. The images were chosen according to the availability of Google Earth images aligned with visible changes in the area of the study branch. In order to confront the evolution of the feature with events that occurred in the region, intenviews were conducted with city hall employees and residents of the region. Rainfall data from the region were also consulted, available on the website of the National Water Agency (ANA).

Other factors influencing the erosive processes were addressed, both the gully and the developing branch. Pascoto (2020) determined the average slope of the contribution area with topographic maps on a scale of 1: 10,000 in the QGIS software. The land use factor of the area was determined through the analysis of aerial images, also with the help of GIS. The classes of land use and the measurement of the factor adopted by the author were based on the methodology of Costa et al. (2018) who conducted a survey of specialists for the study area (São Carlos City - SP).

Table 1 shows the classes considered by the authors and adopted by Pascoto (2020). It is worth noting that the difference in the value attributed to urbanized areas and pasture, or even to arable areas, is high meaning that the consideration of this factor incorrectly can lead to wrong results, making this parameter important for studies related to natural phenomena, especially erosive processes.

Table 1 - Values suggested by Costa et al. (2018) for land use factors

\begin{tabular}{lc}
\hline Land use & Assigned value \\
\hline Fishing farm, artificial water reservoirs & 01 \\
Riparian vegetation, Savanna & 02 \\
Pasture, Power transmission lines, small rural properties & 03 \\
Reforestation and Country House & 10 \\
Sugar cane & 13 \\
Citriculture & 15 \\
Mining, Railroad & 20 \\
Exposed soil, urbanized area, industrial plants, gas station, roads, motels, & 30 \\
intermodal terminal, horticulture, swine and poultry &
\end{tabular}


For this study, the results of indexes obtained through the removal of soil samples carried out by Pascoto (2020), which determined influencing factors related to the geotechnics of the study area, were adopted. Therefore, the factors considered were granulometry, permeability, and soil erodibility. The author collected not deformed and deformed samples, $0.60 \mathrm{~m}$ deep, located in the headland region, in the direction of the development axis, both from the gully and the branch (Figure 2). With the undisturbed samples, some physical indices were determined such as natural specific mass of the soil and soil erodibility. For the specific mass, a PVC ring of $75 \mathrm{~mm}$ in diameter by $40 \mathrm{~mm}$ in height was used, and for the erodibility test, PVC rings of $50 \mathrm{~mm}$ in diameter by $20 \mathrm{~mm}$ in height were used. Due to the difficulty of collecting these samples, for the permeability test it was decided to mold the samples in the laboratory with characteristics similar to the natural one (specific dry mass and natural humidity).

The test to determine the soil granulometry followed the NBR 7181/2018 standard.

To determine the permeability test method, the permeability coefficient was estimated through the literature as a function of the effective diameter presented in the particle size curve, adopting for the gully the variable load method (NBR 13292/1995), and for the branch the constant load method (NBR 14545/2000). The choice of each method considered the values of the estimated coefficients in the order of $10^{-5} \mathrm{~cm} / \mathrm{s}$ and $10^{-1} \mathrm{~cm} / \mathrm{s}$, respectively (PASCOTO, 2020). For the erodibility test, the method of Nogami and Villibor (1979) was used with the limit determined by Pejon (1992).

Figure 2 - Sampling location

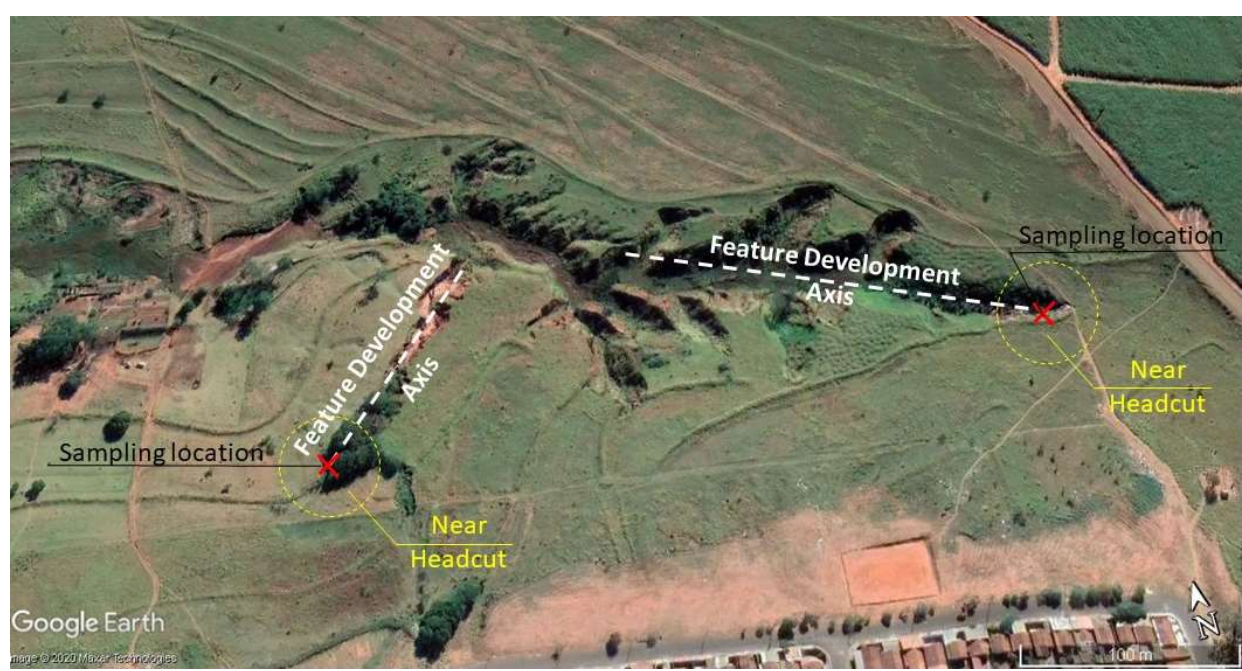


Two distinct contribution areas have also been defined. One being delimited only by relief, by means of the topography of the place, and the other being delimited taking into account the historical evolution of the feature and the information collected related to the urban drainage system in the region provided by the city hall employees. Both contribution areas were determined in square meters and the areas of different uses and occupation existing in the region (pasture, native forest, and urbanized area) in percentage. For the final analysis, a quantitative analysis of these percentages and a qualitative analysis in relation to reality of the contribution area were made.

\section{Results and Discussion}

\subsection{Historical evolution of the feature}

Figure 3 shows the historical evolution of the study gully from 2008 to 2019, with aerial photos obtained by Google Earth from 2008, 2017, and 2019. In the analyzed period, little change in shape, size, and depth of the gully as a whole were noticed, except for the development of the branch, object of this study.

Figure 3 - Historical evolution of the erosive feature from 2008 to 2019

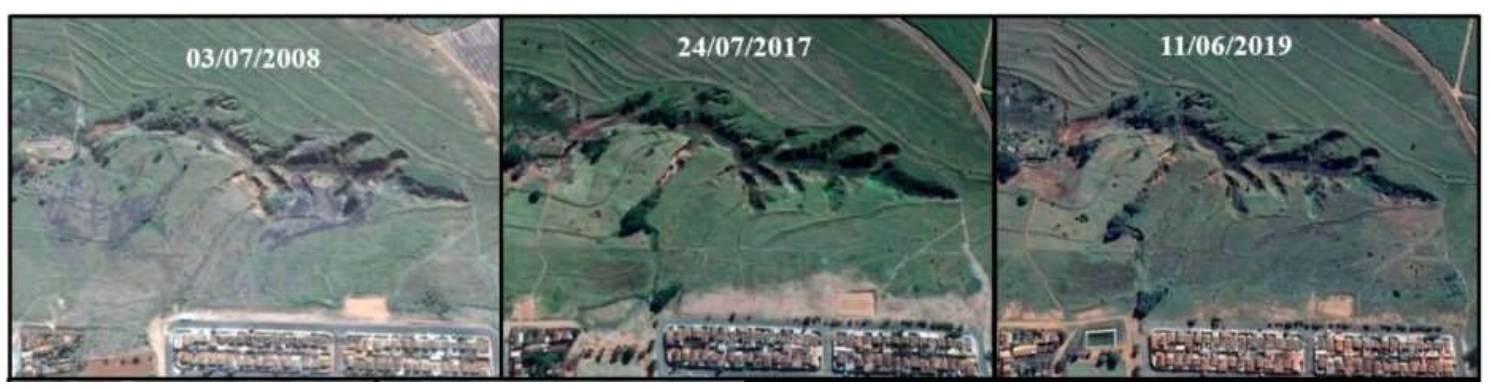

Figure 4 highlights the branch of the erosive feature currently under development, with Google Earth photos from 2010, 2013, 2014, 2015, 2016, 2017, 2018, and 2019. From 2013 to 2015, the feature branch has grown and, after continuous field visits, it was possible to observe that the branch remained active until the end of the research in 2019.

Through interviews with residents of the region and city hall employees, it was discovered that after a rain event from 2013 and 2014, an urban drainage pipe broke whose 
discharge was located in the region of the study feature branch. In fact, inside the branch there is debris from concrete pipes which are believed to be from urban drainage.This drainage network captured rainwater from part of Bairro Paineiras and part of Vila São Geraldo and sent it to the outcrop of water table of the stabilized gully. It was also possible to check that on January 16, 2013, it rained $147.1 \mathrm{~mm}$, and on February 15, 2014, $77.6 \mathrm{~mm}$, in the São Manuel City. These values are different from the average of the maximum daily rainfall for the months of January and February from 2000 to 2014 of $57.2 \mathrm{~mm}$ and $43.4 \mathrm{~mm}$, respectively (ANA, 2018).

Figure 4 - Historical evolution of the erosive feature branch from 2010 to 2019

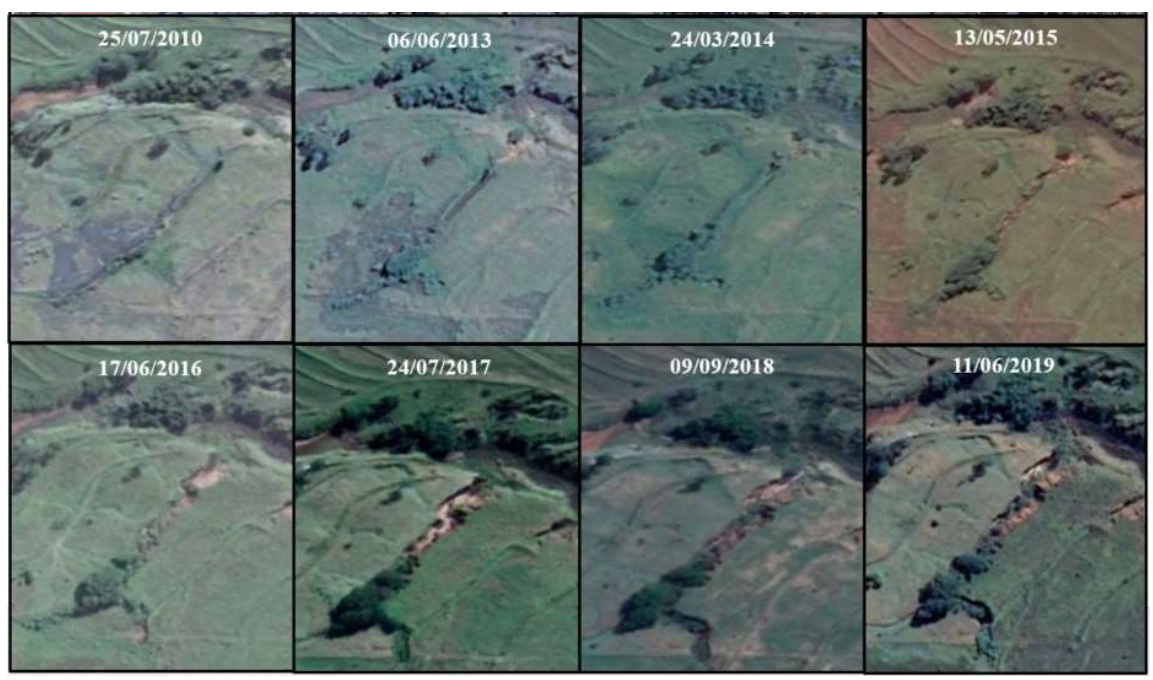

\section{2 Factors influencing erosive processes}

Table 2 shows the factors influencing erosive processes determined by Pascoto (2020). With the results, it is possible to observe that the soil in both places is typically sandy, composed of more than $80 \%$ of sand. The results indicated that the two sites are erodible, as they have $E$ values less than 1.0. Both sites have an average slope classified as mild ( 3 to 8\%) according to EMBRAPA (2006).

The permeability coefficient in the two locations presented different orders of magnitude. According to the literature, coefficients in the order of $10^{-5} \mathrm{~cm} / \mathrm{s}$ are related to clay sands and $10^{-3} \mathrm{~cm} / \mathrm{s}$ related to fine sands (PINTO, 2006). The coefficient of the developing branch, therefore, is in accordance with the literature, while for the gully, there 
is a divergence between the data expected by the literature and those obtained in the tests. This can be explained due to the presence of rubble, domestic waste, and organic matter at the headcut of the gully where the sample was taken for the test.

Table 2 - Factors influencing erosive processes

\begin{tabular}{cccccccc}
\hline Feature & Declivity & $\begin{array}{c}\text { Sand } \\
\text { Fraction }\end{array}$ & $\begin{array}{c}\text { Silt } \\
\text { Fraction }\end{array}$ & $\begin{array}{c}\text { Clay } \\
\text { Fraction }\end{array}$ & $\begin{array}{c}\text { Permeability } \\
\text { Coefficient (cm/s) }\end{array}$ & $\begin{array}{c}\text { Erodibility } \\
\text { (E) }\end{array}$ & $\begin{array}{c}\text { Lan } \\
\text { d use }\end{array}$ \\
\hline Gully & $4,7 \%$ & $81 \%$ & $6 \%$ & $13 \%$ & $2,8 \mathrm{E}-05$ & 0,2 & 3 \\
Branch & $5,1 \%$ & $88,5 \%$ & $4 \%$ & $6 \%$ & $5,2 \mathrm{E}-03$ & 0,2 & 3 \\
\hline
\end{tabular}

Source: adapted from Pascoto (2020)

According to Pascoto (2020), the land use was determined considering the methodology of Costa et al. (2018), adopting the value 3 (pasture, power transmission lines, and small rural properties) for both features. The author adopted the same category of land use for both situations, based only on aerial photos which visually indicated the same predominant proportion of pasture, in relation to urbanization, within the contribution area of each feature.

The conclusion of the study by Pascoto (2020) indicated that although the results of the factors obtained were approximate, the behavior of the two features was different. Therefore, there is a need to further analyze the factors obtained, reaching the conclusion that the land use factor should be reassessed.

\section{3 Analysis of the Feature Contribution area}

The land use factor was determined by analyzing the contribution areas of the study erosive features. In Figure 05, the contribution areas of the gully (in red) and only the branch (in yellow) are highlighted in a Google Earth image of 2020. In order to facilitate the visualization of the relief, due to the scale of the photo, the relief scale was adapted using Google Earth's "Magnify Elevation" tool, adopting 3 times the magnification of the elevations. For the determination of the contribution areas, only the relief of the site was taken into account, determining the areas by means of the level curves, obtaining the results of $347.5 \mathrm{~m}^{2}$ for the entire gully and $56.4 \mathrm{~m}^{2}$ for the branch only. 
With the contribution areas obtained in this way, it is possible to determine that, of the contribution area of the total pot, $9.2 \mathrm{~m}^{2}(2.6 \%)$ uses native forest, $76.9 \mathrm{~m}^{2}(22.1 \%)$ urbanized area, and the remainder, $261.4 \mathrm{~m}^{2}$ (75.3\%) consists of pasture. Moreover, the area with the lowest contribution, from the branch of the feature, is $10.3 \mathrm{~m}^{2}$ of urbanized area (18.3\%) and the remainder, $46.1 \mathrm{~m}^{2}$ (81.7\%) consists of pasture. Analyzing these proportions, it is possible to observe that the percentage of urban area for both features has close values, on average of $20 \%$, even with each feature showing different behavior. This suggests that an analysis using aerial imagery alone may not be sufficient to determine the land use parameter for studies regarding erosive processes. Thus, it was decided to analyze the land use considering the conditions of the drainage system adopted for the areas in question.

Figure 6 shows the amount of the different contribution areas. This time, the areas were determined taking into account the historical evolution of the feature, which points out that the development of the branch occurred due to the rupture of a drainage pipe. It is important to emphasize that this drainage network was designed to capture part of the surface water at the Cohab 4 and Paineiras neighborhoods (Figure 6) and lead them to a single discharge point inside the gully, passing the pipe through the branch.

Figure 5 - Contribution areas of the studied erosive features (image with elevation scale enlarged by 3 times)

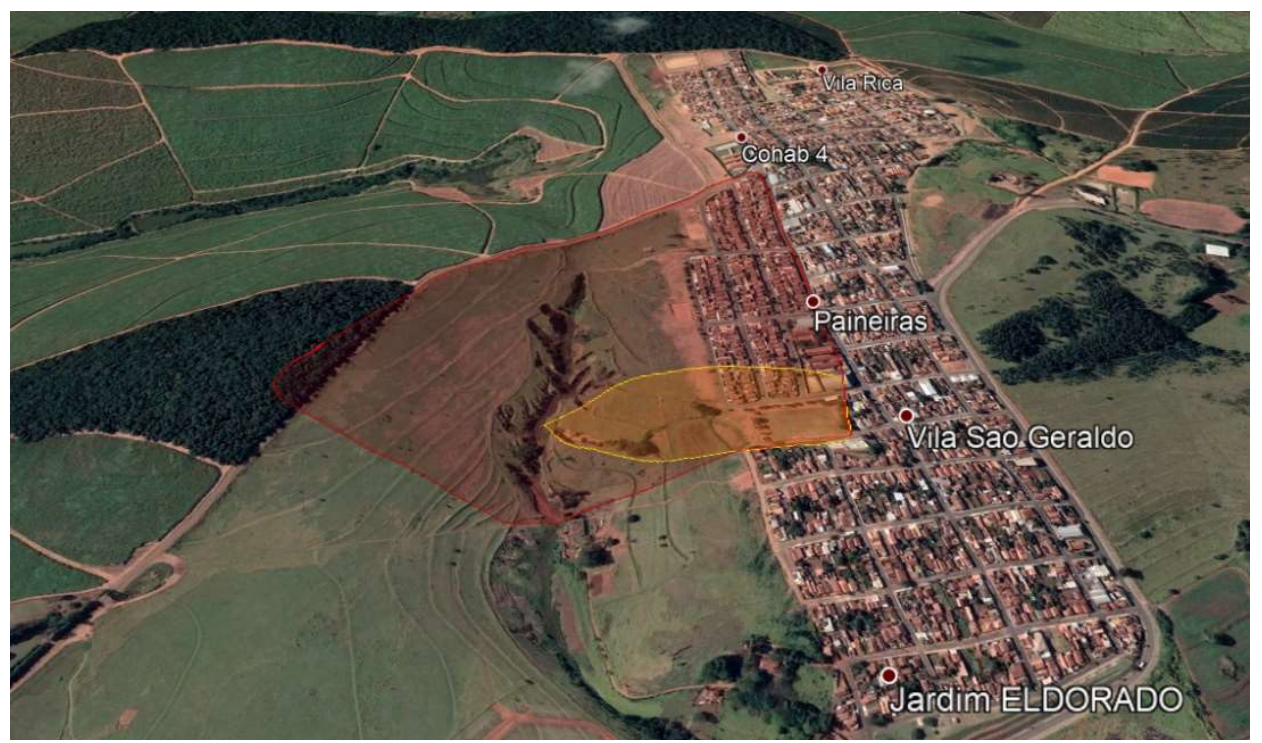


Figure 6 - New delimitation of the contribution areas of the study erosive features (image with elevation scale enlarged by 3 times)

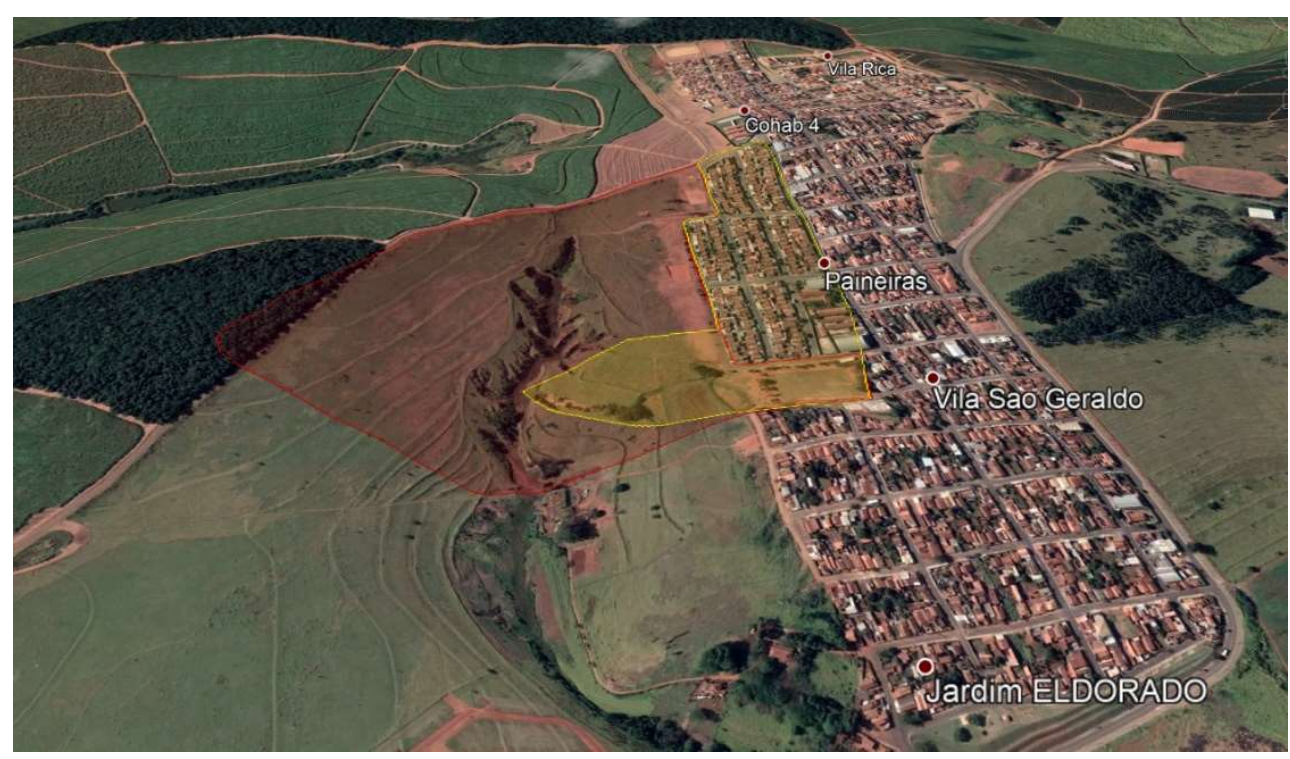

In the new delimitation, it is possible to notice that the percentages of urbanized area in the two features are completely different. The contribution area of the gully is $270.6 \mathrm{~m}^{2}$, while the branch area is approximately $123.0 \mathrm{~m}^{2}$. In the gully area, there is $9.2 \mathrm{~m}^{2}$ of riparian forest (3.4\%) and the rest, $261.4 \mathrm{~m}^{2}(96.6 \%)$ consists of pasture area. Thus, it does not have an urbanized area. On the other hand, of the contribution area of the branch, $46.1 \mathrm{~m}^{2}$ (37.5\%) consists of pasture area and $76.9 \mathrm{~m}^{2}(62.5 \%)$ of urbanized and waterproofed area. Note that the portion of urban area, with $76.9 \mathrm{~m}^{2}$ according to the new delimitation, is larger than the entire contribution area delimited only by the local topography which was initially determined as $56.4 \mathrm{~m}^{2}$ (Figure 5).

The new analysis better explains the greater concentration of flow in the branch region. For the gully, with $96.6 \%$ of pasture and without any urbanized area, the classification as pasture (value 3) would be more accurate. In the case of the branch, however, the indepth analysis indicated $37.5 \%$ of pasture and $62.5 \%$ of urbanized area, which leads to a more accurate classification as an urban area, thus assigning a value of 30. In studies of susceptibility, for example, this difference in assigned values would indicate completely different behaviors for the two situations. 
With this new scenario, it is possible to understand the difference between the stabilization of the gully and the continuity of the branch development. While the processes that occur in the gully have reached a balance, in the branch there is a continuous flow concentration factor, caused by direct anthropic action. In general, these anthropic actions influenced directly or indirectly in practically all factors capable of influencing erosive processes. They changed the detachment, transport, and deposition of soil particles; and, together with the compaction process carried out due to the creation of the neighborhoods, the necessary movement changed the physical characteristics and the structure of the soil. This change may have altered the erodibility of the soil, the behavior of water infiltration, the shape of the slope, the surface roughness, and the average slope of the region. Indirectly, the anthropic action across the macro-region feature may have altered the erosivity of the rains. This can be evidenced due to the occurrence of daily rainfall values much higher than the average maximum rains.

\section{Conclusion}

The joint analysis of the areas of contribution of the erosive feature, of the other factors influencing the erosive processes, of the behavior of these processes over the years, and of the drainage system of the neighborhoods around the feature, led to the conclusion that an analysis of the use factor and only visual occupation based on aerial images, can result in an error in measuring the factor, as happened with the study by Pascoto (2020).

In order to measure the land use factor, therefore, a detailed analysis of the site must be prioritized, taking into account all the means capable of directly and indirectly influencing the flow concentration that contributes to the beginning and development of the erosive feature under study. Greater attention should be paid when the contribution area feature is in urban perimeters, as drainage systems are usually buried, being invisible in aerial images, preventing classification of the contribution area with greater precision.

Considering the importance of the parameter land use in studies related to natural processes, especially erosion processes, the present study demonstrated that the incorrect consideration of this factor can lead to mistaken results. The visual analysis would classify the contribution areas of the studied features as pasture, considering that the two presented 
between 75 and $82 \%$ of pasture, while the analysis with greater criteria would classify the contribution area of the branch as an urbanized area and the gully as a pasture area. .

For the two erosive features studied, therefore, a change is proposed in the consideration of the measurement of the land use factor, in relation to the one considered by Pascoto (2020) who assigned a value of 3 to both features. For the stabilized gully, it is indicated to assign the value 3, while for the branch in development assign a value of 30 .

\section{Acknowledgments}

The authors acknowledge CAPES for the master scholarship granted to the first author.

\section{References}

AGENCIA NACIONAL DE ÁGUAS (ANA): HidroWeb v3.1.1. [cited 2018 out 03]. Available from: http://www.snirh.gov.br/hidroweb/ apresentacao

ARAGÃO, R.; ALMEIDA, J. A. P; FIGUEIREDO, E. E.; SRINIVASAN, V. S. Mapeamento do potencial de erosão laminar na Bacia do Rio Japaratuba, SE, via SIG. Rev. bras. eng. agríc. ambient. 2011;15 (7): 731-740.

CAMAPUM DE CARVALHO, J.; SALES, M. M.; MORTARI, D.; FÁZIO, J. A.; MOTTA, N. O.; FRANCISCO, R. A. Processos Erosivos. In: Camapum de Carvalho J, Sales MM, Souza NM, Melo MTS, editors. Processos Erosivos no Centro-Oeste Brasileiro. Brasília, Distrito Federal: Finatec; 2006. P. 39-91.

COSTA, W. C.; LORANDI, R.; LOLLO, J. A.; IMANI, M.; DUPAS, F. A. Surface runoff and accelerated erosion in a peri-urban wellhead area in southeastern in Brazil. Environ. Earth Sci. 2018; 77:160.

EMPRESA BRASILEIRA DE PESQUISA AGROPECUÁRA (EMBRAPA): Sistema Brasileiro de classificação de solos. $2^{a}$ ed. Brasília: EMBRAPA. 2006. 355 p.

FOSTER, G. R. Understanding Ephemeral Gully Erosion. In: Soil Conservation: An Assessment of the National Resources Inventory. V.2; 1986. p. 90- 128.

IWASA, O. Y.; FENDRICH, R. Controle da Erosão Urbana. In: Oliveira AM. dos S, Brito SNA, editors. Geologia de Engenharia. São Paulo: Associação Brasileira de Geologia de Engenharia; 1998. p. 271-281.

KARMANN, I. Ciclo de Água, Água Subterrânea e Sua Ação Geológica. In: Teixeira W, Toledo MCM, Fairchild TR, Taioli F, editors. Decifrando a Terra. São Paulo: Oficina de Textos; 2000. p. 113-138. 
NASCIMENTO, T. V.; FERNANDES, L. L. Mapeamento de uso e ocupação do solo em uma pequena bacia hidrográfica da Amazônia. Ciênc. Nat. 2017;39(1):169-177.

NOGAMI, J. S.; VILLIBOR, D. F. Soil characterization of mapping units for highway purposes in a tropical area. Bulletin of International Association of Engineering Geology, Krefeld. 1979; 19: 196-199.

PEJON, O. J. Mapeamento Geotécnico da Folha de Piracicaba - SP (Escala 1:100.000): Estudo de aspectos metodológicos, de caracterização e de apresentação dos atributos - volume 1 [thesis]. São Carlos: Escola de Engenharia de São Carlos/USP; 1992. 241p.

PENA, L. L. S.; LADISLAU, F. F. Crítica ao zoneamento de uso e ocupação do solo como um instrumento de gestão na sub-bacia hidrográfica do Ribeirão da Cachoeirinha - Belo Horizonte/ Minas Gerais. In: : Proceedings of the XVII Smpósio Brasileiro de Geografia Física Aplicada [CD-ROM]; 2017 jun 28 - jul 02; Campinas, Brasil. p. 467-478.

PASCOTO, T. V. Análises Fatorial e de Componentes Principais aplicadas ao estudo dos fatores influenciadores de processos erosivos [dissertation]. Bauru: Faculdade de Engenharia de Bauru, Universidade Estadual Paulista "Júlio de Mesquita Filho"; 2020. 123p.

PASCOTO, T. V.; FUREGATTI, S. A.; PEIXOTO, A. S. P. CLASSIFICAÇÃO das erosões da área urbana de São Manuel - SP. In: Proceedings of the XIX Congresso Brasileiro de Mecânica dos Solos e Engenharia Geotécnica. Salvador - BA [CD- ROM]; 2018 ag 28 - set 01; Salvador, Brasil. vol V. p. 354.

PINTO, C. S. Curso básico de mecânica dos solos em 16 aulas. 3ed. São Paulo: Oficina de texto; 2006. 367p.

SANTOS, A. S. R. M.; MAURO, T. L.; SOUZA, L. A.; SENIGALIA, R. L. C.; CASTRO, D. A.; SANTOS, E. S. (2019). Métodos de classificação supervisionada aplicados no uso e ocupação do solo no município de Presidente Médice - RO. Rev. Biodivers. 2019;18(1):150-159.

SALOMÃO, F. X. T. Controle e prevenção dos processos erosivos. In: Guerra AJT, Silva AS, Botelho RGM, editors. Erosão e conservação dos solos. Rio de Janeiro: Bertrand Brasil; 1999. p.229-267.

SECRETARIA DE ESTADO DE SANEAMENTO E RECURSOS HÍDRICOS: Plano Municipal de Saneamento. São Paulo, 2017. 179p.

TAGLIARINI, F. S. N.; RODRIGUES, M. T.; RODRIGUES, B. T.; CAMPOS, S. Índices NDVI e NDWI como ferramentas ao mapeamento do uso e ocupação em bacia hidrográfica. In: Proceedings of the Anais do XVIII Simpósio Brasileiro de Sensoriamento Remoto; 2017 mai 28-31; Santos, Brasil. p. 2271- 2278.

TRINDADE, S. P.; RODRIGUES, R. A. Uso do solo na microbacia do Ribeirão Samambaia e sua relação com a suscetibilidade à erosão laminar. Rev. Geogr. Acad. 2016;10(1): 163-181. 